\title{
Isolation, characterization and heterologous expression of a novel chitosanase from Janthinobacterium sp. strain 4239
}

\author{
Mads G Johnsen ${ }^{1}$, Ole C Hansen ${ }^{1}$, Peter Stougaard ${ }^{2 *}$
}

\begin{abstract}
Background: Chitosanases (EC 3.2.1.132) hydrolyze the polysaccharide chitosan, which is composed of partially acetylated $\beta$-(1,4)-linked glucosamine residues. In nature, chitosanases are produced by a number of Gram-positive and Gram-negative bacteria, as well as by fungi, probably with the primary role of degrading chitosan from fungal and yeast cell walls for carbon metabolism. Chitosanases may also be utilized in eukaryotic cell manipulation for intracellular delivery of molecules formulated with chitosan as well as for transformation of filamentous fungi by temporal modification of the cell wall structures.

However, the chitosanases used so far in transformation and transfection experiments show optimal activity at high temperature, which is incompatible with most transfection and transformation protocols. Thus, there is a need for chitosanases, which display activity at lower temperatures.

Results: This paper describes the isolation of a chitosanase-producing, cold-active bacterium affiliated to the genus Janthinobacterium. The $876 \mathrm{bp}$ chitosanase gene from the Janthinobacterium strain was isolated and characterized. The chitosanase was related to the Glycosyl Hydrolase family 46 chitosanases with Streptomyces chitosanase as the closest related (64\% amino acid sequence identity). The chitosanase was expressed recombinantly as a periplasmic enzyme in Escherichia coli in amounts about 500 fold greater than in the native Janthinobacterium strain.

Determination of temperature and $\mathrm{pH}$ optimum showed that the native and the recombinant chitosanase have maximal activity at $\mathrm{pH} 5-7$ and at $45^{\circ} \mathrm{C}$, but with $30-70 \%$ of the maximum activity at $10^{\circ} \mathrm{C}$ and $30^{\circ} \mathrm{C}$, respectively.

Conclusions: A novel chitosanase enzyme and its corresponding gene was isolated from Janthinobacterium and produced recombinantly in E. coli as a periplasmic enzyme. The Janthinobacterium chitosanase displayed reasonable activity at $10^{\circ} \mathrm{C}$ to $30^{\circ} \mathrm{C}$, temperatures that are preferred in transfection and transformation experiments.
\end{abstract}

\section{Background}

Chitin, a polymer of acetylated $\beta$-(1,4)-linked glucosamine (GlcNAc) residues, is the second-most abundant polysaccharide in nature, where it constitutes the major structural component in a number of organisms, e.g. crustaceans, insects, nematodes and fungi. Chitosan, which is a partly deacetylated form of chitin, is less abundant but may be found in the cell wall of certain fungi, e.g. Zygomycetes [1,2] and green algae like Chlorella [3]. Chitin and chitosan have similar molecular structures, since both polysaccharides are made up of $\beta$ -

\footnotetext{
* Correspondence: psg@life.ku.dk

${ }^{2}$ Section of Genetics and Microbiology, Department of Agriculture and Ecology, Faculty of Life Sciences, University of Copenhagen, Thorvaldsensvej 40, DK-1871 Frederiksberg C, Denmark
}

(c) 2010 Johnsen et al; licensee BioMed Central Ltd. This is an Open Access article distributed under the terms of the Creative Commons Attribution License (http://creativecommons.org/licenses/by/2.0), which permits unrestricted use, distribution, and reproduction in any medium, provided the original work is properly cited. (1,4)-linked glucosamine $(\mathrm{GlcN})$ residues, which are 50$100 \%$ acetylated (chitin) or $0-50 \%$ acetylated (chitosan) [4]. In recent years, interest in oligosaccharides derived from chitin and especially from chitosan has increased considerably because these oligosaccharides are watersoluble and possess useful biological activities like antitumor and antimicrobial activities [5-10]. The oligosaccharides may be produced by chemical treatment of polymeric chitosan or may be derived from enzymatic hydrolysis of chitosan.

Enzymes capable of hydrolyzing chitosan, chitosanases (EC 3.2.1.132), may be found in a number of organisms, particularly in microorganisms. Chitosanases are classified into five glycoside hydrolase families: GH-5, GH-8, GH-46, GH-75 and GH-80 [11]. Enzymes from families 
GH-5 and GH-8 may hydrolyze a number of other glycosides besides chitosan, whereas glycoside hydrolase families GH-46, GH-75 and GH-80 only comprise chitosanases. Among these true chitinases, the chitosanases from Streptomyces and Bacillus have been studied in detail with respect to e.g. catalytic features and molecular structure [12-15]. In addition to members of the genera Streptomyces and Bacillus, chitosanases have been isolated from a number of other Gram-positive and Gram-negative bacteria e.g. Acinetobacter sp. [16], Amycolatopsis sp. [17], Serratia marcescens [18], Pseudomonas sp. [19], Nocardioides sp. [20], Microbacterium sp. [21], as well as from fungi, e.g. Gongronella sp. [22], Aspergillus oryzae [23] and Fusarium solani [24].

Normally, gene delivery using chitosan microparticles will result in low transfection frequency compared to liposome mediated gene delivery [25]. However, recently it has been shown that gene delivery of DNA complexed with chitosan into mammalian cells may be enhanced if a fungal chitosanase gene is co-expressed inside the cells [26]. Similarly, hydrolytic enzymes, e.g. chitosanases, are used for transformation of filamentous fungi by modification of the cell wall structure, making the cell more accessible. So far, the chitosanases, which have been used in such transformation and transfection experiments, have shown optimal temperatures around $60^{\circ} \mathrm{C}$, and the enzymes are hardly active at the low temperatures, which are preferable in transfection and transformation experiments. Therefore, we have screened a bacterial strain collection from Greenland and isolated a chitosanase-producing, cold-active Janthinobacterium sp. isolate. In this paper, we describe the isolation and characterization of a new chitosanase and we show that the enzyme may be produced heterologously in Escherichia coli resulting in high yields.

\section{Results}

\section{Isolation of chitosanase enzyme and gene from} Janthinobacterium sp

Three thousand bacterial isolates were screened for chitosanase activity on agar plates with chitosan. Thirty isolates were found to produce clear haloes around the colonies after four days of incubation at $20^{\circ} \mathrm{C}$. Phylogenetic analysis showed that the isolates, which produced the largest haloes were related to Janthinobacterium, Pedobacter and Eubacterium. One isolate, no. 4239, from a fresh water lake close to Kangerlussuaq in West Greenland produced the largest clearing haloes and was selected for further investigations. Phylogenetic analysis by $16 \mathrm{~S}$ rRNA sequencing showed that the isolate was affiliated to the genus Janthinobacterium. A gene library of Janthinobacterium sp. 4239 was constructed in pUC18 in E. coli and plated onto agar medium including chitosan. After four days of incubation at $20^{\circ} \mathrm{C}$, two transformants, which produced small haloes, were identified. Restriction enzyme analysis indicated that the plasmids in the two clones were identical, and one of the plasmids, pMGJ1061, was selected for subsequent sequence analysis and subcloning. Sequencing of the insert revealed two open reading frames, one encoding the chitosanase (Fig. 1) and one encoding a putative aspartate decarboxylase with reverse orientation (not shown). The open reading frame coding for a chitosanase contained two ATG codons that may both work as translation start codons. Initiation at the first ATG codon (bp 749-751) will result in a polypeptide of 291 amino acid residues $(876 \mathrm{bp}$ ) including a signal peptide of 24 amino acid residues as determined by SignalP and LipoP algorithms. The amino acid residues around the proposed cleavage site showed similarity to lipoprotein like sites for signal peptidase II cleavage (Fig. 1). Initiation at the second ATG codon (bp 848-850) results in a polypeptide of 258 amino acid residues comprising a putative signal peptide of 18 amino acid residues with a lipoprotein like site for signal peptidase I cleavage (Fig. 1). BLASTP analysis of the mature 267 amino acid polypeptide starting at the first initiation codon showed similarity to glycosyl hydrolase family 46 chitosanase sequences (Streptomyces sp. 63\% [GenBank:P33665] and 64\% [GenBank:ZP_05001348]; Streptosporangium roseum 64\% [GenBank:ZP_04476321]; Amycolatopsis sp. 64\% [GenBank:BAA94840]). Detailed studies of the Streptomyces chitosanase protein structure have emphasized the importance of certain amino acid residues in relation to catalysis and structure. The equivalent amino acid residues of the Janthinobacterium sp. 4236 chitosanase are shown in bold in the protein sequence presented in Fig. 1.

\section{Heterologous expression of Janthinobacterium chitosanase in $E$. coli}

The part of the gene encoding the mature protein (267 amino acids), initiated at the first start codon but without the signal sequence, was further subcloned into an expression vector. In this plasmid, named pBMS172, the chitosanase gene was fused with E. coli ompA sequence, substituting the native Janthiobacterium signal sequence. Transformants with plasmid pBMS172 showed haloes around the colonies, confirming that the fragment encoded a polypeptide with chitosanase activity. Denaturing zymographic gel electrophoresis and activity staining revealed that the mature secreted product found in the periplasm of BMS172 migrated to a position corresponding to that of the native chitosanase product of $33 \mathrm{kDa}$ (Fig. 2A), isolated from growth medium. In a similar gel system not including the chitosan substrate the same recombinant chitosanse migrated to a position corresponding to $31 \mathrm{kDa}$, which is in closer 
agreement with the size of $29 \mathrm{kDa}$ deduced from the sequence analyses (Fig. 2B). The sub-cellular distribution of the chitosanase activity was investigated by determining the enzyme activity in fractionated cellular compartments. Recombinant E. coli harbouring plasmid pBMS172 expressed chitosanase activity in about 500 fold greater amounts per cell when compared to the native Janthinobacterium sp. 4239 isolate (Table 1). From $50 \mathrm{ml}$ of flask culture a raw periplasmic extract of $1.25 \mathrm{ml}$ was obtained. This extract contained $6.0-6.5 \mathrm{mg}$ recombinant chitosanase protein and provided 3.0-3.5 mg highly purified chitosanase product. Over-expression of chitosanase and periplasmic accumulation of the enzyme posed considerable stress on the E. coli transformant. This effect was evident from the high ratio observed between periplasmic and cytoplasmic activity of glucose-6-phosphate dehydrogenase (G6PD, a cytoplasmic marker), when compared to a control strain (Table 1). Preliminary characterization experiments with the recombinant chitosanase produced in $E$. coli 


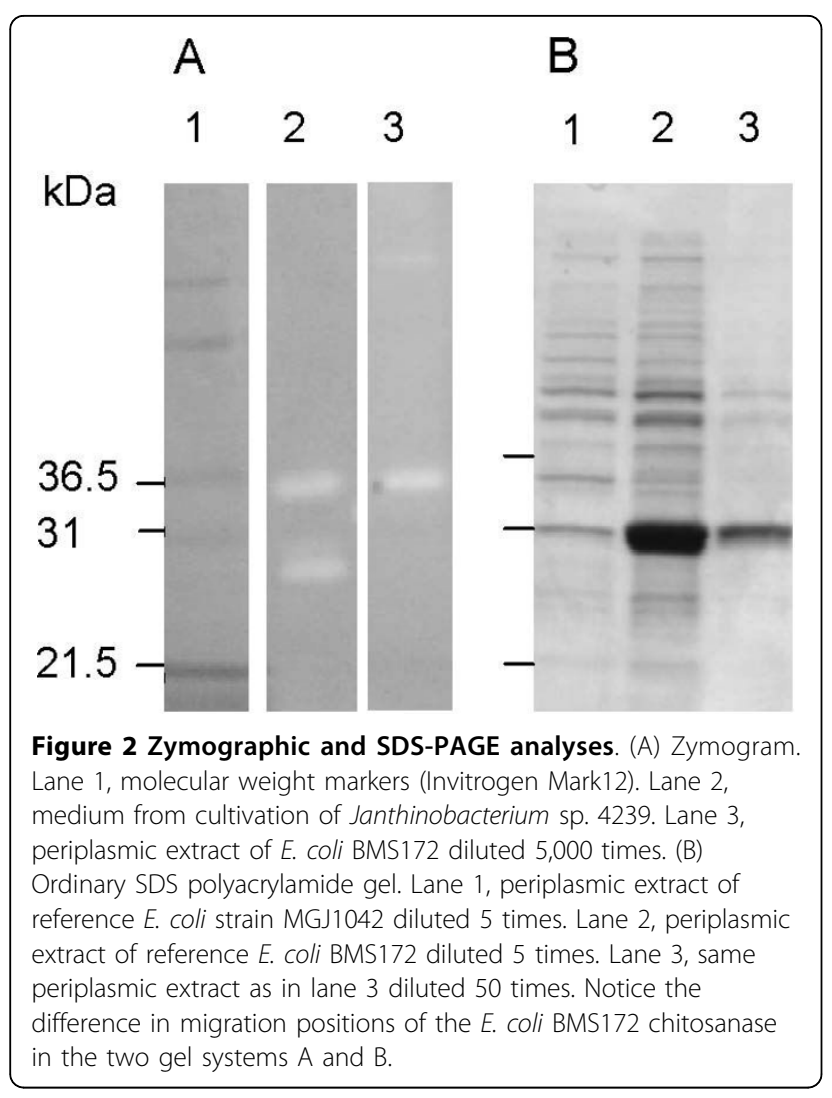

BMS172 gave results similar to those obtained with the native $33 \mathrm{kDa}$ enzyme (data not shown). Therefore, since purification of periplasmic chitosanase was easier, detailed characterization of enzyme performance was carried out on chitosanase from E. coli pBMS172.

\section{Characterization of chitosanase from Janthinobacterium}

Purified chitosanase produced by E. coli pBMS172 was analyzed with respect to substrate specificity. The recombinant chitosanase displayed high relative activity on chitosan with $80 \%$ deacetylation and a peak molecular weight of $1000 \mathrm{kDa}$ (Table 2). The specific activity on this substrate was found to be $1500 \mathrm{U} / \mathrm{mg}\left(45^{\circ} \mathrm{C}\right)$. Slightly lower activity was observed on chitosan with lower peak molecular weight $(500 \mathrm{kDa}$ and $700 \mathrm{kDa}$ ) and on $55 \%$ deacetylated chitosan. No activity was
Table 2 Relative chitosanase activity on different substrates

\begin{tabular}{ll}
\hline Substrate & Relative act (\%) \\
\hline Chitosan $80 \% \mathrm{DD}, 1000 \mathrm{kDa}$ & 100 \\
\hline Chitosan $80 \% \mathrm{DD}, 700 \mathrm{kDa}$ & 87 \\
\hline Chitosan 80\% DD, $500 \mathrm{kDa}$ & 84 \\
\hline Chitosan 55\% DD & 68 \\
\hline Colloidal chitin & 0 \\
\hline Insoluble cellulose & 0 \\
\hline CM cellulose & 0 \\
\hline Beta-1,3-glucan & 0 \\
\hline Xylan & 0 \\
\hline Arabinoxylan & 0 \\
\hline
\end{tabular}

$\mathrm{DD}$, degree of deacetylation. CM, carboxymethylated

observed on chitin, cellulose, glucan, xylan or arabinoxylan substrates (Table 2). TLC analysis of the products from hydrolysis of chitosan hexamer showed that digestion with recombinant chitosanase resulted in only dimers and trimers of glucosamine. In contrast, concentrated medium from Janthinobacterium sp. 4239 culture was able to hydrolyze the hexameric substrate into monomers and dimers (Fig. 3).

Determination of temperature optimum was conducted with $80 \%$ deacetylated chitosan substrate (Fig.4). Purified chitosanase from E. coli pBMS172 displayed maximal activity at $45^{\circ} \mathrm{C}$ and $30-70 \%$ of the maximal activity was observed at $10-30^{\circ} \mathrm{C}$. The recombinant chitosanase was stable at temperatures up to $50^{\circ} \mathrm{C}$ above which the enzyme activity decreased rapidly and hardly remained after treatment at $70^{\circ} \mathrm{C}$ for $30 \mathrm{~min}$. Determination of the $\mathrm{pH}$ optimum was conducted with $80 \%$ deacetylated chitosan. The chitosanase displayed a broad pH optimum between $\mathrm{pH} 5$ and 7 (Fig. 5). Hardly any activity was left at $\mathrm{pH} 8$ and above.

\section{Discussion}

Previously, Janthinobacterium strains degrading chitin have been reported $[27,28]$ but this report is the first to describe a chitosanase from the genus Janthinobacterium. Polyacrylamide gel electrophoresis and zymographic staining revealed that two polypeptides with the apparent molecular weights of 27.5 and $33 \mathrm{kDa}$ were

Table 1 Cellular distribution of chitosanase activity

\begin{tabular}{|c|c|c|c|c|}
\hline \multirow[b]{2}{*}{ Strains } & \multicolumn{3}{|c|}{ Chitosanase specific activity ${ }^{\mathrm{a}}$ units $\cdot \mathrm{OD}_{600}{ }^{-1} \cdot \mathrm{ml}^{-1}$} & \multirow{2}{*}{$\frac{\text { G6PD }^{\text {activity }}{ }^{\mathbf{b}} \%}{\mathrm{PER} / \mathrm{CYT}}$} \\
\hline & CYT & PER & MED & \\
\hline Janthinobacterium 4239 & 0.016 & 0.007 & 0.035 & - \\
\hline E. coli BMS172 & 17.8 & 20.3 & 1.25 & 62 \\
\hline E. coli MGJ1042 (control) & 0.002 & 0 & 0 & 23 \\
\hline
\end{tabular}

${ }^{a}$ Specific chitosanase activity is presented as units $(\mu \mathrm{mol} / \mathrm{min})$ of reducing ends released per milliliter of cells with $\mathrm{OD}_{600}=1\left(\mathrm{U} \cdot \mathrm{OD}_{600}{ }^{-1} \cdot \mathrm{ml}^{-1}\right)$. $\mathrm{CYT}_{\text {, }} \mathrm{cytoplasmic}$ extract. PER, periplasmic extract. MED, culture medium obtained after centrifugation. ${ }^{b}$ Glucose-6-phosphate dehydrogenase (G6PD) is a cytoplasmic marker indicating the degree of cell lysis. Periplasmic extract of Janthinobacterium sp. strain 4239 showed no G6PD activity. 


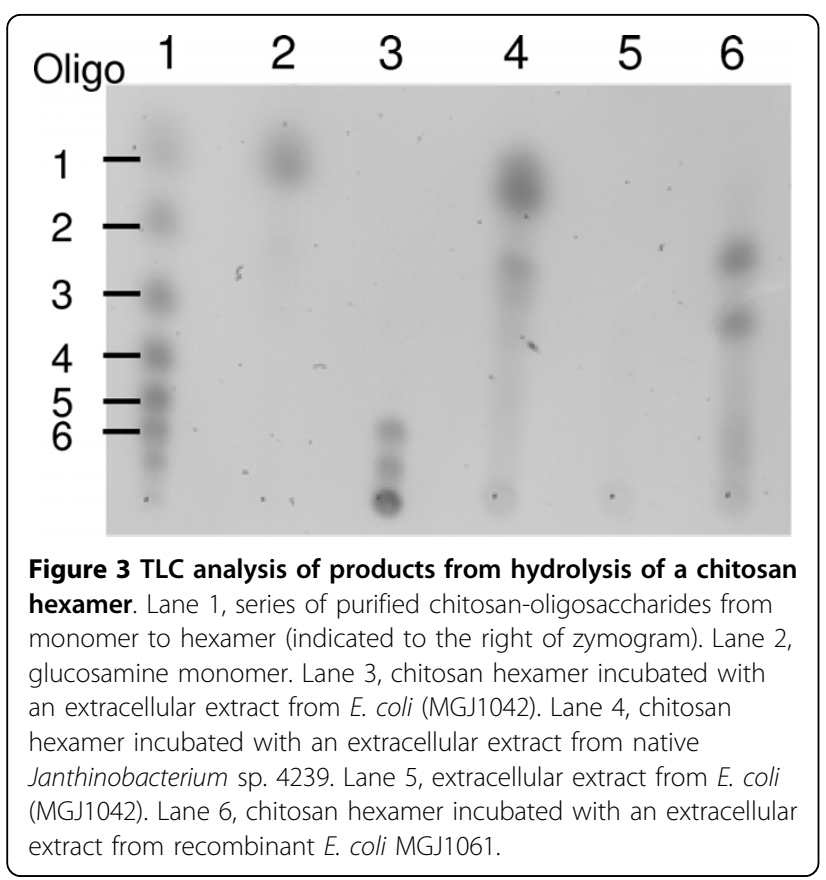

able to hydrolyze chitosan (Fig. 2A, lane 2). This observation suggested that Janthinobacterium sp. strain 4239 harbours two different chitosanase genes, and that in the subsequent screening of the genomic library in $E$. coli only one of the genes were isolated in this study. However, another explanation for the two bands in extracellular extracts from native Janthinobacterium sp. 4239 cells may be that the strain produces two enzyme variants from the isolated cho4239-1 gene by using two different translation initiation positions and/or by cleavage at two different positions in the polypeptide chain. Apparently, the presence of chitosan substrate in the zymographic gel influences the migration position of the

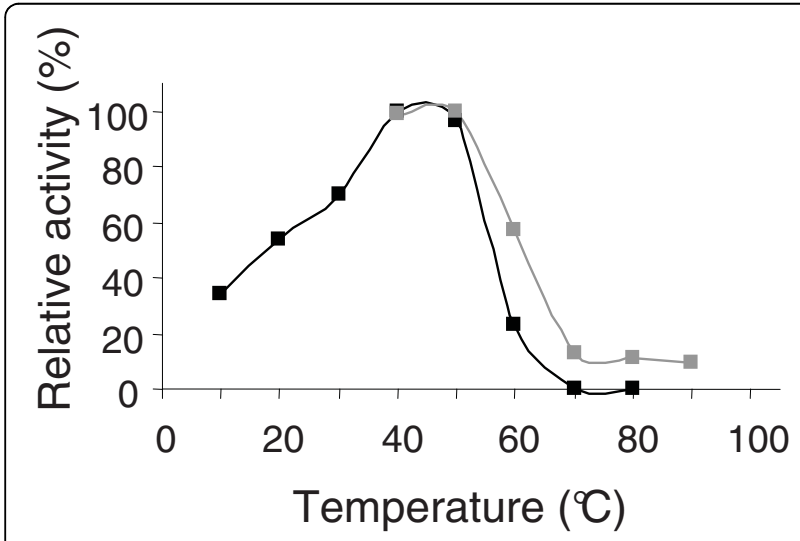

Figure 4 Influence of temperature on chitosanase activity and stability. Black squares and lines: Relative activity. Gray squares and lines: relative activity after incubation at the same temperature for $30 \mathrm{~min}$.

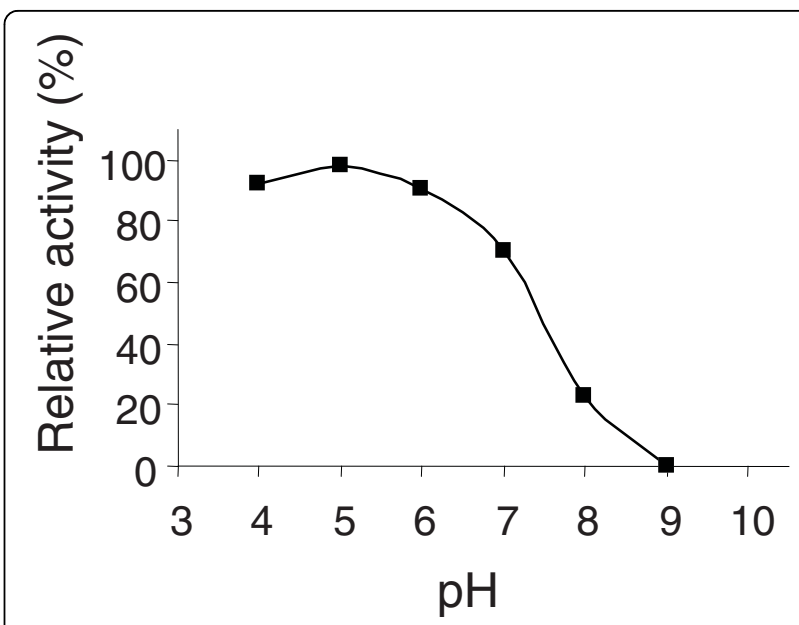

Figure 5 Influence of $\mathbf{p H}$ on chitosanase activity. Relative activity was determined using $80 \%$ deacetylatd chitosan.

recombinant chitosanase product. The $27.5 \mathrm{kDa}$ chitosan hydrolytic product from the native Janthinobacterium sp. 4239 may also not be size estimated entirely correctly in the zymogram. If this second chitosan hydrolyzing protein is a result of translational initiation at the second putative start position the expected molecular size is expected to be $28.1 \mathrm{kDa}$. However, we can not from our data conclude if Janthinobacterium sp. 4239 harbours one or two chitosanase gene(s).

Expression of the Janthinobacterium chitosanase in $E$. coli resulted in large amounts of recombinant chitosanase in the periplasm (BMS172). Also, a large amount of recombinant protein accumulated in the cytoplasm, suggesting that the efficiency of the expression system could be further improved by introducing elements that promote secretion. SDS-PAGE showed that the monomeric molecular weight of the chitosanase secreted by the BMS172 construct was $33 \mathrm{kDa}$, which is similarly to the larger of the two products secreted by the native Janthinobacterium sp. strain 4239 (Fig. 2, lane 2).

In agreement with the affiliation to glycosyl hydrolase family 46 , based on protein homology, the ability of the chitosanase to convert chitosan hexamers into dimers and trimers further emphasizes the relation with endochitosanases. However, hexamer substrate conversion by crude extracellular protein from Janthinobacterium sp. 4239 resulted in monomeric glucosamine accumulation, suggesting that the native bacterium also produces exobeta-D-glucosaminidase activity in addition to endohydrolytic chitosanase activity.

The chitosanase displayed 64\% amino acid sequence identity with the well-characterized chitosanase from Streptomyces sp. N174. Alignment of the Janthinobacterium sp. 4239 chitosanase with that of Streptomyces sp. N174 revealed the presence of a putative catalytic 
residue at $\mathrm{Glu}_{22}$ (Streptomyces numbering). However, an equivalent of $\mathrm{Asp}_{40}$, which is also believed to be involved in catalysis in most - if not all - chitosanases from family GH-46, was not found. However, it has been shown [29] that an Asp to Gly mutation in position 40 in Streptomyces sp. N174 chitosanase did not affect the stereochemical mechanism of catalysis or the mode of interaction with the substrate. In stead, other accessory active site residues, $\mathrm{Glu}_{36}$ and $\mathrm{Thr}_{45}$, were shown to be involved in catalysis. Examination of the Janthinobacterium sp. 4239 chitosanase sequence (Fig. 1) shows the presence of a glutamine residue similar to the $\mathrm{Glu}_{36}$ and a threonine one residue from the $\mathrm{Thr}_{45}$ residue in the Streptomyces sp. N174 chitosanase. Thus, it may be possible that the Janthinobacterium sp. 4239 chitosanase uses the Glu $\mathrm{G}_{36}$ residue as a catalytic residue.

\section{Conclusions}

This study provides a chitosanase affiliated to glycosyl hydrolase family 46 with specificity towards chitosan substrate and with activity at conditions favourable for transformation and transfection experiments. The ease, at which the chitosanase can be produced in E. coli and accumulated in the periplasm, provides a product with few impurities suitable for many experimental procedures. The application value of this enzyme can now be tested in protocols relying on efficient hydrolysis at low to moderate temperatures.

\section{Methods \\ Materials}

Chitosan samples with peak molecular weights of $500,000,700,000$ and 1,000,000 g/mol, respectively, and all with a degree of deacetylation of more than $80 \%$ were obtained from Cognis Deutschland GmbH\&Co., KG (Düsseldorf, Germany). The chitosan (more than $80 \%$ deacetylated) used for preparing screening plates was obtained from Carbomer (Westborough, MA, USA). A specified preparation of water-soluble chitosan (WSC) with peak molecular weight of $2,500,000 \mathrm{~g} / \mathrm{mol}$ and a degree of deacetylation of $55 \%$ was obtained from Primex ehf. (Reykjavik, Iceland). Carboxymethylcellulose and Avicel were obtained from Sigma-Aldrich. Crab flakes for colloidal chitin preparation were obtained from Carbomer (Westborough, MA, USA). The chitosan-oligosaccharides were obtained from Seikagaku Corporation (Japan). Restriction enzymes were from New England Biolabs and Fermentas.

\section{Isolation and characterization of chitosanase-producing strain}

Samples of microorganisms were collected at various locations along the West-coast of Greenland in 2000.
Soil, sediment and water samples were plated on M9 medium supplemented with different carbohydrates. Strain 4239 was isolated from a fresh water lake close to Kangerlussuaq. The screening medium was prepared from stocks. A chitosan stock for one liter of medium was obtained by autoclaving $1.8 \mathrm{~g}$ of insoluble chitosan in $200 \mathrm{ml}$ of demineralized water. Once room temperature was reached, the chitosan was brought in solution by adding $18 \mathrm{ml}$ of sterile $1 \mathrm{M} \mathrm{HCl}$. The chitosan was dissolved during stirring for two hours and then the entire stock was poured into $700 \mathrm{ml}$ of autoclaved warm, sterile medium at a slow rate during vigorous stirring in order to maintain small colloidal particles. To prepare $700 \mathrm{ml}$ of medium, $9 \mathrm{~g}$ of $\mathrm{KH}_{2} \mathrm{PO}_{4}, 6 \mathrm{~g}$ of $\mathrm{K}_{2} \mathrm{HPO}_{4}, 8 \mathrm{~g}$ of tryptone (Difco), $4 \mathrm{~g}$ of yeast extract (Difco) and $15 \mathrm{~g}$ of agar was mixed. The medium was further supplemented with $2 \mathrm{ml}$ of Vogels Trace Elements $\left(5 \mathrm{~g}\right.$ of citric acid. $\mathrm{H}_{2} \mathrm{O}, 5 \mathrm{~g}$ of $\mathrm{ZnSO}_{4} \cdot 7 \mathrm{H}_{2} \mathrm{O}, 1 \mathrm{~g}$ of $\mathrm{Fe}\left(\mathrm{NH}_{4}\right)_{2}\left(\mathrm{SO}_{4}\right)_{2} \cdot 6 \mathrm{H}_{2} \mathrm{O}, 0.25 \mathrm{~g}$ of $\mathrm{CuSO}_{4} \cdot 5 \mathrm{H}_{2} \mathrm{O}, 0.05 \mathrm{~g}$ of $\mathrm{MnSO}_{4} \cdot \mathrm{H}_{2} \mathrm{O}, 0.05 \mathrm{~g}$ of $\mathrm{H}_{3} \mathrm{BO}_{4}$ and $0.05 \mathrm{~g}$ of $\mathrm{Na}_{2} \mathrm{MoO}_{4} \cdot 2 \mathrm{H}_{2} \mathrm{O}$ per $100 \mathrm{ml}$, sterilized by filtration). Finally, $2 \mathrm{ml}$ of a sterile solution of $\mathrm{MgSO}_{4} \cdot 6 \mathrm{H}_{2} \mathrm{O}(203$ $\mathrm{g} / \mathrm{l})$ was added. Before use, the final volume was adjusted to 1 liter with sterile water. The isolated Janthinobacterium sp. strain 4239 was propagated for four days at $20^{\circ} \mathrm{C}$ in baffled, conical culture flasks containing the complete chitosan growth medium without agar and aerated by shaking. Supernatants were concentrated on spin filters (Amicon, $10 \mathrm{kDa}$ cut-off) and analyzed for protein content and activity. Material for DNA isolation was obtained by incubation of cells for two days in a medium, in which the chitosan was substituted by 2.5 $\mathrm{ml}$ of $20 \%$ glucose per liter. Screening of E. coli transformants expressing chitosanase was carried out on LB agar plates supplemented with $1.8 \mathrm{~g} / \mathrm{l}$ of chitosan prepared as described above.

\section{Phylogenetic analysis}

The 16S PCR product was generated with the primers presented in Table 3 . The product was sequenced by primer walking and the information was deposited in GenBank [GenBank:GQ487532].

\section{Molecular cloning of chitosanase gene}

Isolation of chromosomal DNA from Janthinobacterium sp. 4239 was carried out from a $100 \mathrm{ml}$ cell culture which was harvested at $\mathrm{OD}_{600}=3$. The cells were harvested by centrifugation, resuspended in $10 \mathrm{ml}$ of $\mathrm{TE}$ buffer (10 mM Tris. $\mathrm{HCl}, \mathrm{pH} 7.5,1 \mathrm{mM}$ EDTA) and frozen at $-20^{\circ} \mathrm{C}$. The cells were thawed and incubated with $1 \%(\mathrm{w} / \mathrm{v}) \mathrm{SDS}, 2 \mathrm{mg}$ of proteinase $\mathrm{K}$ (Roche) and $0.1 \mathrm{mg}$ of RNaseA. After incubation at room temperature for 30 min, $1.8 \mathrm{ml}$ of $5 \mathrm{M} \mathrm{NaCl}$ was added. Phase separation was enhanced by the addition of $1.5 \mathrm{ml}$ of $10 \%(\mathrm{w} / \mathrm{v})$ 
Table 3 Bacteria, plasmids and oligonucleotide primers

\begin{tabular}{|c|c|c|}
\hline Name & Characteristics & Reference or origin \\
\hline \multicolumn{3}{|c|}{ Janthinobacterium sp. 4239} \\
\hline & Gram negative, chitosanolytic, no chitinolytic activity detected. & This study \\
\hline \multicolumn{3}{|l|}{ E.coli } \\
\hline $\mathrm{DH} 10 \mathrm{~B}$ & 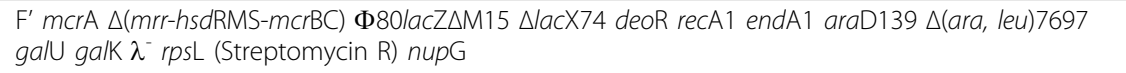 & Invitrogen \\
\hline MGJ1042 & DH10B:pMGJ1042. Reference strain. & This study \\
\hline MGJ1061 & DH10B:pMGJ1061. Chromosomal library clone expressing Cho4239-1. & This study \\
\hline BMS172 & DH10B:pBMS172. Construction expressing Cho4239-1 fused with the OmpA signal peptide. & This study \\
\hline \multicolumn{3}{|l|}{ Plasmids } \\
\hline pUC18 & lacUV5 promoter, Ampr', ColEl origin, 2.69 kb. & [40] \\
\hline pMGJ1042 & $\begin{array}{l}\text { pMF1::OmpA-Sphl fragment. tet }{ }^{\mathrm{p} / \mathrm{o}} \text { promoter, } \mathrm{Cm}^{\mathrm{r}} \text {, proAB complementation and ColEl replication } \\
\text { origin. }\end{array}$ & {$[36]$} \\
\hline pMGJ1061 & pUC18::4 kb chromosomal fragment encoding Cho4239-1. & This study \\
\hline pBMS172 & pMGJ1042::815 bp PCR fragment digested with Sphl/BamHI and fused with OmpA signal peptide. & This study \\
\hline \multicolumn{3}{|c|}{ Oligonucleotide primers } \\
\hline chodel4239-1.for & 5'-ACATGCATGCGGCGGCGGAGAACAGC-3' & Construction of pBMS172 \\
\hline cho4239-1.rev3 & 5'-CGCGGATCCGCGGCTGTTTAGCGGATCTGGT-3' & Construction of pBMS172 \\
\hline $616 \mathrm{~V}$ & 5'-AGAGTTTGATYMTGGCTCAG-3' & 16S RNA sequence \\
\hline $630 \mathrm{R}$ & 5'-CAKAAAGGAGGTGATCC-3' & 16S RNA sequence \\
\hline
\end{tabular}

hexadecyl-trimethyl ammonium bromide (CTAB) dissolved in $0.7 \mathrm{M} \mathrm{NaCl}$. The subsequent extraction steps were conducted essentially as described by Marmur [30]. Chromosomal DNA was isolated after two rounds of phenol/chloroform/isoamyl alcohol extractions and two chloroform/isoamyl alcohol extractions, followed by addition of one volume of 2-propanol for precipitation. Finally, the DNA was spooled onto a sterile inoculation needle and washed several times in $70 \%(\mathrm{v} / \mathrm{v})$ ethanol. The yield of purified DNA obtained from a $100 \mathrm{ml}$ cell culture was estimated to $200 \mu \mathrm{g}$. The DNA was dissolved in TE-buffer and stored at $5^{\circ} \mathrm{C}$.

A DNA library was constructed by partial digestion of $24 \mu \mathrm{g}$ of chromosomal DNA using 0.8 units of the restriction enzyme Bsp1431 (an isoscizomer of Sau3A). After 15 min the partially digested DNA was heat treated at $65^{\circ} \mathrm{C}$ for $10 \mathrm{~min}$. DNA fragments above $3 \mathrm{~kb}$ in size were purified by agarose gel electrophoresis. The fragments were ligated into plasmid pUC18 digested with the restriction enzyme $B a m \mathrm{HI}$, and the ligation mixture was transformed into electrocompetent E. coli strain DH10B cells (Gibco BRL). A total of 40,000 transformants were plated onto LB plates supplemented with $1.8 \mathrm{~g}$ of chitosan per liter. E. coli colonies expressing chitosanase were identified by the appearance of clearing zones around the colonies.

\section{Nucleotide sequence analysis}

One of the E. coli isolates contained a pUC18 plasmid with a $4 \mathrm{~kb}$ insert, plasmid pMGJ1061. DNA sequencing of the insert in pMGJ1061 was carried out using custom ordered primers from DNA Technology (Aarhus, Denmark). Reactions were analyzed with an ALF Express sequencer (Pharmacia). Inserts were sequenced on both strands using plasmid specific primers and primer walking. Basic DNA analysis was carried out in DNA Star (Lasergene) and database searches for homologous sequences were carried out using the BLAST program [31]. Multiple alignment of amino acid sequences was performed with the ClustalX program [32]. A putative Nterminal signal peptide was identified by SignalP version 3.0 and LipoP server facilities [33]. The DNA sequence of Janthinobacterium sp. 4239 chitosanase, Cho4239-1, was deposited in GenBank [GenBank:GQ487533].

\section{Subcloning and expression in $E$. coli}

Heterologous expression of Janthinobacterium sp. 4239 chitosanase in $E$. coli was carried out using vector pMGJ1042, a derivative of plasmid pMF1 [34,35]. Secretion from this plasmid has been improved by introduction of the native OmpA signal peptide cleavage site as described previously [36]. The chitosanase gene from Janthinobacterium sp. 4239 was isolated by PCR with primers specific for the cho4239-1 gene (Table 3). The DNA fragment was restricted with SphI and BamHI and inserted into pMGJ1042 also digested with these enzymes. In this plasmid, pBMS172, the putative catalytic part of the chitosanase gene was fused to the OmpA. The insert of plasmid pBMS172 was sequenced, and growth experiments on chitosan-containing agar plates with chloramphenicol $(30 \mu \mathrm{g} / \mathrm{ml})$ and tetracycline 
(10 $\mathrm{ng} / \mathrm{ml})$ confirmed the identity of the plasmid (Table 3).

Recombinant chitosanase was produced from $50 \mathrm{ml}$ cultures of E. coli cells harbouring plasmid pBMS172. The cells were grown in enforced medium (16 g bactotryptone (Difco), 16 g yeast extract (Difco), $5 \mathrm{~g} \mathrm{NaCl}$, $2.5 \mathrm{~g} \mathrm{~K}_{2} \mathrm{HPO}_{4}$ per liter) and when the $\mathrm{OD}_{600}$ reached 2, the cultures were induced with $250 \mu \mathrm{g} / \mathrm{ml}$ of anhydrotetracycline for 5-5.5 h.

\section{Assay procedures}

Chitosanase activity was determined as the rate at which reducing molecules were generated. Reducing ends were quantitated by reaction with potassium ferricyanide stain [37] and converted to molecules by reference to a standard curve of reduced stain intensity versus different amounts of GlcN. The buffer systems outlined by Keith and Morrison [38] were used for testing activity at different $\mathrm{pH}$ values. The highly deacetylated chitosan substrates were dissolved in $25 \mathrm{mM} \mathrm{HCl}$ before adjusting the assay $\mathrm{pH}$. In standard assay conditions substrate chitosan with a peak molecular weight of $1,000 \mathrm{kDa}$ and $80 \%$ deacetylation was dissolved in $\mathrm{HCl}$ and equilibrated to $\mathrm{pH} 5.5$ with $150 \mathrm{mM}$ $\mathrm{NH}_{4}$ Ac-buffer. One unit of chitosanase was defined as the amount of enzyme that liberates $1 \mu \mathrm{mol}$ of d-glucosamine per min under the conditions described above. The glucose-6-phosphate dehydrogenase (G6PD) activity was assayed in extracts from an equal number of cells. In this assay the formation of NADH during glucose-6-phophate conversion was determined at $340 \mathrm{~nm}$.

\section{Extraction and purification of Janthinobacterium chitosanase}

Bacterial cell pellets were obtained by centrifugation and then mixed with an equal volume of extraction buffer (2.5 mM EDTA and $20 \mathrm{mM}$ Tris. $\mathrm{HCl}, \mathrm{pH}$ 6.5). Three successive cycles of freezing and thawing were conducted for the specific extraction of periplasmatic proteins [39]. After precipitation of the remaining cell content, the cytoplasm was extracted in the same buffer by FastPrep (Bio101) treatment including a 1:1 volume ratio of $102 \mathrm{~nm}$ glass beads (Sigma) at speed 5.5 for three times $20 \mathrm{sec}$. For long-term storage, the extracts were preserved with $50 \%(\mathrm{v} / \mathrm{v})$ glycerol and kept at $-20^{\circ}$ C. For storage less than a week, the extract were preserved by addition of $1.5 \mathrm{mM} \mathrm{NaN}_{3}$ and kept in the refrigerator. Chitosanase was purified from periplasmic extract by gel filtration on a Superdex 75 HR 10/30 column (GE Healthcare). The column was equilibrated and eluted with $50 \mathrm{mM}$ potassium phosphate, $150 \mathrm{mM}$ $\mathrm{NaCl}, \mathrm{pH}$ 6.5. Chitosanase containing fractions were pooled and analyzed by SDS-PAGE (Invitrogen). The quantity of the purified chitosanase protein was estimated relative to the intensity of molecular weight markers (Mark12, Invitrogen).

\section{Characterization of chitosanase}

Zymographic polyacrylamide gels were cast with $30 \%$ ProtoGel 37.5:1 and ProtoGel buffers from National Diagnostics. In the separation gel $0.025 \%(w / v)$ WSC chitosan was included. Prior to loading the gels, the enzyme samples were denatured by heat treatment for 3 $\min$ at $100^{\circ} \mathrm{C}$. The sample buffer was prepared as a twofold stock solution by mixing $15 \mathrm{ml}$ of $50 \%(\mathrm{w} / \mathrm{v})$ sucrose, $10 \mathrm{ml}$ of $10 \%(\mathrm{w} / \mathrm{v})$ SDS and $5 \mathrm{ml}$ of $1 \mathrm{M}$ Tris. $\mathrm{HCl}, \mathrm{pH}$ 6.8. After electrophoresis, gels were renatured by overnight incubation in phosphate buffer, $\mathrm{pH}$ 6.5, stained with 0.1\% Fluorescent Brightner 28 (Sigma) in $0.5 \mathrm{M}$ Tris. $\mathrm{HCl}, \mathrm{pH} 9$ for $5 \mathrm{~min}$, and destained in several changes of demineralized water for a period of 3-4 h. Zymographic gel section with marker proteins and acrylamide gels without chitosan substrate were stained with Coomassie Brilliant Blue. Results were documented by UV $(312 \mathrm{~nm})$ exposure and photography. TLC experiments were conducted on Silica Gel 60 plates (Merck) with oligosaccharides and glucosamine as references. The mobile phase was prepared by mixing 100 $\mathrm{ml}$ of 1-propanol and $50 \mathrm{ml}$ of $25 \%$ (v/v) ammonia (Merck). The separation was conducted over two runs each taking about $6 \mathrm{~h}$. After drying, the plates were sprayed with $5 \%(\mathrm{v} / \mathrm{v}) \mathrm{HCl}$ in ethanol and heated for 10 min in an oven at $170^{\circ} \mathrm{C}$.

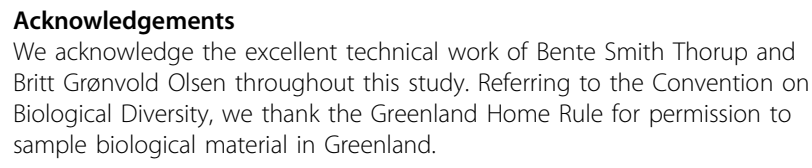
Britt Grønvold Olsen throughout this study. Referring to the Convention on Biological Diversity, we thank the Greenland Home Rule for permission to sample biological material in Greenland.

\section{Author details}

${ }^{1}$ Bioneer A/S, Kogle Allé 2, DK-2970 Hørsholm, Denmark. ${ }^{2}$ Section of Genetics and Microbiology, Department of Agriculture and Ecology, Faculty of Life Sciences, University of Copenhagen, Thorvaldsensvej 40, DK-1871 Frederiksberg C, Denmark.

\section{Authors' contributions}

PS coordinated the project, planned the field trip and sampled the biological material. PS and MGJ established the strain collection. MGJ screened the strain collection, isolated chitosanase-producing bacteria and performed all molecular biology work. OCH conducted all protein purifications. All authors have read and approved the final version of the manuscript.

\section{Competing interests}

The authors declare that they have no competing interests.

Received: 14 November 2009

Accepted: 22 January 2010 Published: 22 January 2010

\section{References}

1. Fenton DM, Eveleigh DE: Purification and mode of action of a chitosanase from Penicillium islandicum. J Gen Microbiol 1981, 126:151-165. 
2. Pochanavanich $P$, Suntornsuk W: Fungal chitosan production and its characterization. Lett Appl Microbiol 2002, 35:17-21.

3. Davis B, Eveleigh DE: Chitosanases: occurrence, production and immobilization. Chitin, Chitosan and Related Enzymes New York: Academic PressZikakis JP 1984, 161-179

4. Khor E: The relevance of chitin. Chitin: Fulfilling a biomaterials promise Oxford, United Kingdom: Elsevier Science LtdKhor E, First 2001, 1-8.

5. Hirano S, Nagao N: Effects of chitosan, pectic acid, lysozyme and chitinase on the growth of several phytopathogens. Agric Biol Chem 1989, 53:3065-3066.

6. Kendra DF, Hadwiger LA: Characterization of the smallest chitosan oligomer that is maximally antifungal to Fusarium solani and elicits pisatin formation in Pisum sativum. Exp Mycol 1984, 8:276-281.

7. Suzuki K, Mikami T, Okawa Y, Tokoro A, Suzuki S, Suzuki M: Antitumor effect of hexa-N-Acetylchitogexaose and chitohexose. Carbohydr Res 1986, 151:403-408

8. Suzuki S: Studies on biological effects of water soluble lower homologous oligosaccharides of chitin and chitosan. Fragrance J 1996, 15:61-68.

9. Tokoro A, Kobayashi M, Tatekawa N, Suzuki S, Suzuki M: Protective effects of $\mathrm{N}$-acetylchitohexaose of Listeria monocytogenes infection in mice. Microbiol Immunol 1989, 33:357-367.

10. Tsukada K, Matsumoto T, Aizawa K, Tokoro A, Naruse R, Suzuki S, Suzuki M: Antimetastatic and growth-inhibitory effects of $\mathrm{N}$-acetylchitohexaose in mice bearing Lewis lung carcinoma. Jpn J Cancer Res 1990, 81:259-265.

11. The glycoside hydrolase family server; Carbohydrate Active enzymes, CAZy. http://www.cazy.org/fam/acc_GH.html.

12. Fukamizo T, Brzezinski R: Chitosanase from Streptomyces sp. strain N174: a comparative review of its structure and function. Biochem Cell Biol, Biochimie et Biologie Cellulaire 1997, 75:687-696.

13. Honda Y, Fukamizo T, Okajima T, Goto S, Boucher I, Brzezinski R: Thermal unfolding of chitosanase from Streptomyces sp. N174: role of tryptophan residues in the protein structure stabilization. Biochim Biophys Acta 1999, 1429:365-376.

14. Marcotte EM, Monzingo AF, Ernst SR, Brzezinski R, Robertas JD: X-ray structure of an anti-fungal chitosanase from Streptomyces N174. Nature Structural Biology 1996, 3:155-162.

15. Saito J-I, Kita A, Higuchi Y, Nagata Y, Ando A, Miki K: Crystal structure of chitosanase from Bacillus circulans MH-K1 at, 1.6-尺̊ resolution and its substrate recognition mechanism. J Biol Chem 1999, 274:30818-30825.

16. Shimosaka M, Nogawa M, Wang XY, Kumehara M, Okazaki M: Production of two chitosanases from a chitosan-assimilating bacterium, Acinetobacter sp. strain CHB101. Appl Environ Microbiol 1995, 61:438-442.

17. Okajima S, Ando A, Shinoyama H, Fujii T: Purification and characterization of an extracellular chitosanase produced by Amycolatopsis sp. CsO-2. J Ferment Bioeng 1994, 77:617-620

18. Wang SL, Peng JH, Liang TW, Liu KC: Purification and characterization of a chitosanase from Serratia marcescens TKU011. Carbohydr Res 2008, 343:1316-1323.

19. Ando A, Saito A, Arai S, Usuda S, Furuno M, Kaneko N, Shida O, Nagata Y: Molecular characterization of a novel family-46 chitosanase from Pseudomonas sp. A-01. Biosci Biotech Bioch 2008, 72:2074-2081.

20. Masson JY, Boucher I, Neugebauer WA, Ramotar D, Brzezinski R: A new chitosanase gene from a Nocardioides $\mathrm{sp}$. is a third member of glycosyl hydrolase family 46. Microbiology 1995, 141:2629-2635.

21. Zhang J, Sun Y: Molecular cloning, expression and characterization of a chitosanase from Microbacterium sp. Biotechnol Lett 2007, 29:1221-1225.

22. Wang J, Zhou W, Yuan H, Wang Y: Characterization of a novel fungal chitosanase Csn2 from Gongronella sp. JG. Carbohydr Res 2008, 343:2583-2588

23. Zhang XY, Dai AL, Zhang XK, Kuroiwa K, Kodaira R, Shimosaka M, Okazaki M: Purification and characterization of chitosanase and exo-B-Dglucosaminidase from a koji mold, Aspergillus oryzae IAM 2660. Biosci Biotechnol Biochem 2000, 64:1896-1902.

24. Shimosaka M, Kumehara M, Zhang X-Y, Nogawa M, Okazaki M: Cloning and characterization of a chitosanase gene from the plant pathogenic fungus, Fusarium solani. J Ferment Bioeng 1996, 82:426-431.

25. Prabaharan M, Mano JF: Chitosan-based particles as controlled drug delivery systems. Drug Deliv 2005, 12:41-57.
26. Zuo A, Sun P, Liang D, Liu W, Zhao R, Guo G, Cheng N, Zhang J, Yao K: Improved transfection efficiency of CS/DNA complex by co-transfected chitosanase gene. Int J Pharm 2008, 352:302-308.

27. Gleave AP, Taylor RK, Morris BA, Greenwood DR: Cloning and sequencing of a gene encoding the $69-\mathrm{kDa}$ extracellular chitinase of Janthinobacterium lividum. FEMS Microbiol Lett 1995, 131:279-288.

28. Xiao X, Yin X, Lin J, Sun L, You Z, Wang P, Wang F: Chitinase genes in lake sediments of Ardley Island, Antarctica. Appl Environ Microbiol 2005, 71:7904-7909.

29. Lacombe-Harvey M-E, Fukamizo T, Gagnon J, Ghinet MG, Dennhart N, Letzel T, Brzezinski R: Accessory active site residues of Streptomyces sp. N174 chitosanase. FEBS Journal 2009, 276:857-869.

30. Marmur J: A procedure for the isolation of deoxyribonucleic acid from microorganisms. J Mol Biol 1961, 3:208-218.

31. Altschul SF, Madden TL, Schaffer AA, Zhang J, Zhang Z: Gapped BLAST and PSI-BLAST: a new generation of protein database search programs. Nucleic Acids Res 1997, 25:3389-3402.

32. Thompson JD, Gibson TJ, Plewniak F, Jeanmougin F, Higgins DG: The CLUSTAL_X windows interface: flexible strategies for multiple sequence alignment aided by quality analysis tools. Nucleic Acids Res 1997, 25:4876-4882.

33. Bendtsen JD, Nielsen H, von Heijne G, Brunak S: Improved Prediction of Signal Peptides: SignalP 3.0. J Mol Biol 2004, 340:783-795.

34. Fiedler M, Skerra A: proBA complementation of an auxotrophic E. coli strain improves plasmid stability and expression yield during fermenter production of a recombinant antibody fragment. Gene 2001, 274:111-118.

35. Skerra A: Use of the tetracycline promoter for the tightly regulated production of a murine antibody fragment in Escherichia coli. Gene 1994, 151:131-135.

36. Rasmussen MA, Madsen SM, Stougaard P, Johnsen MG: Flavobacterium sp. strain 4221 and Pedobacter sp. strain 4236 beta-1,3-glucanases that are active at low temperatures. Appl Environ Microbiol 2008, 22:7070-7072.

37. Imoto T, Yagishita K: A simple activity measurement of lysozyme. Agric Biol Chem 1971, 35:1154-1156.

38. Keith $\mathrm{K}$, Morrison JF: Buffers of constant ionic strength for studying $\mathrm{pH}$ dependent processes. Methods in enzymology, vol 87 London, Academic PressPurich DL 1982, 405-426.

39. Souzu H: Studies on the damage to Escherichia coli cell membrane caused by different rates of freeze-thawing. Biochim Biophys Acta 1980, 603:13-26.

40. Yanisch-Perron C, Vieira J, Messing J: Improved M13 phage cloning vectors and host strains: nucleotide sequences of the M13mp18 and pUC19 vectors. Gene 1985, 33:103-119.

doi:10.1186/1475-2859-9-5

Cite this article as: Johnsen et al.: Isolation, characterization and heterologous expression of a novel chitosanase from Janthinobacterium sp. strain 4239. Microbial Cell Factories 2010 9:5.

\section{Submit your next manuscript to BioMed Central and take full advantage of:}

- Convenient online submission

- Thorough peer review

- No space constraints or color figure charges

- Immediate publication on acceptance

- Inclusion in PubMed, CAS, Scopus and Google Scholar

- Research which is freely available for redistribution

Submit your manuscript at www.biomedcentral.com/submit
Biomed Central 